\title{
PERONEAL NERVE PALSY DUE TO COMPARTMENT SYNDROME AFTER FACIAL PLASTIC SURGERY
}

\author{
Clécio O. Godeiro-Júnior', Acary Sousa Bulle Oliveira', \\ André Carvalho Felício', Newton Barros², Alberto Alain Gabbai'
}

\begin{abstract}
A 25-year-old white man, right after bilateral rhytidoplasty, presented with agitation, necessiting use of haloperidol. Some hours after, he developed severe pain in his legs and a diagnosis of neuroleptic malignant syndrome (NMS) was considered. Even with treatment for NMS he still complained of pain. A diagnosis of lower limb compartment syndrome (CS) was done only 12 hours after the initial event, being submitted to fasciotomy in both legs, disclosing very pale muscles, due to previous ischemia. This syndrome was not explained only by facial surgery, his position and duration of the procedure. It can be explained by a sequence of events. He had a history of pain in his legs during physical exercises, usually seen in chronic compartment syndrome. He used to take anabolizant and venlafaxine, not previously related, and the agitation could be related to serotoninergic syndrome caused by interaction between venlafaxine and haloperidol. Rhabdomyolisis could lead to oedema and ischmemia in both anterior leg compartment. This report highlights the importance of early diagnosis of compartment syndrome, otherwise, even after fasciotomy, a permanent disability secondary to peripheral nerve compression could occur.
\end{abstract}

KEY WORDS: compartment syndrome, plastic surgery, rhytidoplasty, peroneal nerve.

\section{Paralisia de nervo fibular devido a síndrome compartimental após cirurgia plástica da face}

RESUMO - Logo após ritidoplastia bilateral, um jovem de 25 anos apresentou agitação, necessitando uso de haloperidol. Algumas horas após, desenvolveu dor intensa em membros inferiores, e o diagnóstico de síndrome neuroléptica maligna foi considerado. Mesmo com o tratamento para tal, persistiu com dor. Após 12 horas do início do quadro, foi realizado o diagnóstico de síndrome compartimental de membros inferiores e o jovem foi submetido a fasciotomia bilateral. Uma seqüência de eventos desencadeou esta síndrome, já que sua ocorrência dificilmente seria justificada pela cirurgia facial e/ou posição do paciente durante o procedimento. O jovem apresentava previamente dor em membros inferiores aos exercícios, sugerindo a ocorrência de uma síndrome compartimental crônica. Ele fazia uso de anabolizantes e venlafaxina, não relatado no início do quadro, e a agitação poderia ser explicada por uma síndrome serotoninérgia desencadeada pela interação deste último medicamento e haloperidol. A rabdomiólise secundária a estes eventos causou edema e isquemia nos compartimentos anteriores de ambos os membros inferiores, levando a uma compressão secundária do nervo fibular. O caso em questão ilustra a importância do diagnóstico precoce da síndrome compartimental pois, caso contrário, mesmo com fasciotomia, uma complicação permanente devido à compressão de nervos periféricos pode se estabelecer.

PALAVRAS-CHAVE: síndrome compartimental, cirurgia plástica, ritidoplastia, nervo fibular.

Compartment syndrome (CS) develops when pressure within closed osseofascial compartments increases, reducing capillary perfusion gradient, leading to cellular anoxia and harming tissue viability, especially muscles and nerves. Several etiologies for CS have been described in the literature but the leading cause is posttraumatic injury ${ }^{1-3}$. Long-duration surgeries (urological, colorectal, and gynecological procedures) in lithotomy position are recognized causes of $\mathrm{CS}^{4-8}$. There are few reports on CS during prolonged supine surgeries.
We report an unusual case of chronic bilateral lower limb CS with acute exacerbation after a shortduration plastic surgery (rhytidoplasty).

\section{CASE}

A healthy 25-year-old white man was admitted at our institution in order to perform a facelifting (rhytidoplasty) procedure. Pre-anesthetic evaluation or laboratory exams were unremarkable. Three years before, the same patient had been submitted to another plastic surgery due to gynecomastia without complications.

\footnotetext{
1Department of Neurology and Neurosurgery, Escola Paulista de Medicina, Universidade Federal de São Paulo, São Paulo SP, Brazil; ${ }^{2}$ Department of Vascular Surgery, Escola Paulista de Medicina, Universidade Federal de São Paulo, São Paulo SP, Brazil.
}

Received 12 February 2007, received in final form 11 April 2007. Accepted 23 May 2007. 
The patient was laid in supine position and general anesthesia was performed with propofol, midazolam and phentanyl. Surgical procedure lasted about 40 minutes. Over the following five hours, the patient became agitated and received midazolam and haloperidol.

He was admitted to the medical ICU and remained agitated, complaining of intense pain and tightness on both lower limbs. Tramadol and diazepam were administered with partial relief of pain. On clinical exam he was somnolent, had bilateral pretibial edema and severe pain on his legs, especially with ankle dorsiflexion. Rare fasciculations were seen on thighs. Muscle strength was graded IV on lower limbs except for grade II on ankle dorsiflexion. There were no abnormalities on reflexes. Pupils were normal. Vital signs were as follows: temperature $37,9^{\circ} \mathrm{C}$; respiration 27 per minute; pulse 111 beats per minute; and blood pressure 150/90 mmHg. Arterial blood gas obtained on room air revealed a pH of 7.44, PCO2 37, PO2 81 and oxygen saturation of $96 \%$. Biochemical work-up showed: glucose $91 \mathrm{mg} /$ $\mathrm{dL}$; creatinine $1.1 \mathrm{mg} / \mathrm{dL}$; potassium $3.9 \mathrm{mEq} / \mathrm{L}$; sodium 142 $\mathrm{mEq} / \mathrm{L}$; aspartate aminotransferase $484 \mathrm{IU} / \mathrm{L}$; alanine aminotransferase $180 \mathrm{IU} / \mathrm{L}$. The creatinekinase (CK) level measurement was $28,464 \mathrm{IU} / \mathrm{L}$.

The patient received aggressive hydratation and IV $\mathrm{NaHCO} 3$ was given to alkalinize the urine. Regarding the contracture in his legs, a diagnosis of neuroleptic malignant syndrome (NMS) was considered, and intravenous dantrolene was administered.

After 12 hours of NMS therapy the patient clinical condition did not improve. He still complained of severe pain in both legs especially with ankle dorsiflexion. On examination, bilateral pretibial edema and ankle arreflexia were detected. Peripheral arterial pulses remained intact. Another serum CK was 43,240 IU/L. At that time, his parents informed that he used to take on a regular basis steroid anabolisant, anphetamine and venlafaxine $75 \mathrm{mg} /$ day for depression, and that he also used to complain of pain and paresthesias on lower limbs during physical exercises.

Considering the diagnosis of CS, a fasciotomy was performed bilaterally, on the anterior and lateral compartments disclosing very pale muscles, due to previous ischemia (Figure). He was discharged from the hospital 33 days after fasciotomy without pain but with bilateral peroneal nerve palsy.

\section{DISCUSSION}

The diagnosis of CS must be done early, otherwise, even with fascectomy, peripheral nerve complications are certain ${ }^{9}$. CS diagnosis is based on clinical findings, but frequently it is not promptly recognized, even when known traditional risk factors are present. The main risk factors responsible for developing CS are fracture and soft tissue compromise ${ }^{1-3}$, surgeries $^{4-8}$, physical exertion ${ }^{10-13}$, and exogenous intoxication leading to rhabdomyolysis ${ }^{14,15}$. The clinical features of CS are: pain that worsens with exertion, tense compartment, weakness and paresthesias ${ }^{3,10}$. Peripheral pulsation is intact until compartment pressure reaches dyastolic pressure ${ }^{2}$. The main subsidiary exam that helps with the diagnosis is measurement of the intracompartment pressure that is normally around 0 to $15 \mathrm{mmHg}^{2,3}$. In CS, values of intracompartment pressure are often greater than $40 \mathrm{mmHg}^{1-3,10}$. Other auxiliary exams may also help in the diagnosis such as muscle enzymes and Doppler ultra-sound ${ }^{1,10}$. Recently, magnetic resonance imaging has been used as a diagnostic tool, especially in cases of exertional $\mathrm{CS}^{13}$.

Bilateral CS has been frequently described in pro-

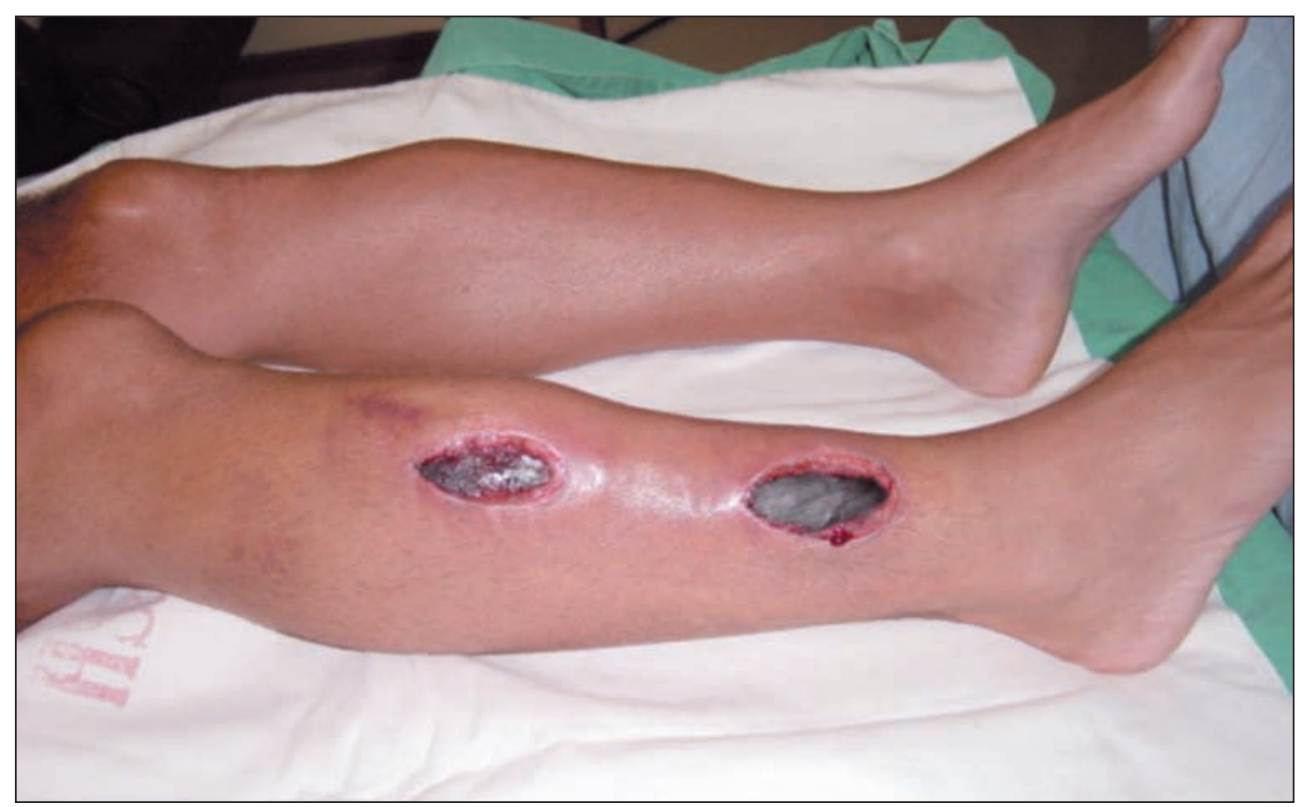

Figure. Bilateral fasciectomy. Necrotic areas on pretibial compartment are shown. 
longed, more than 6 hours, lithotomy position ${ }^{4-7}$. This event is rarely related to a surgical procedure in supine position ${ }^{8}$. Rhytidectomy is considered a secure procedure and the complications described are associated directly to procedure: hematoma, inflammation, crusting, hypertrophic scars, hair loss, and changes in ear lobe appearence ${ }^{16}$. Bilateral CS has never been described.

Our patient was submitted to less than 40 minutes plastic surgery (rhytidoplasty) in supine position, which would not be considered as a risk factor for the development of bilateral CS, explaining the delay for the diagnosis in our report. His past medical history was relevant due to frequent complain of pain and paresthesias during exercise. We may hypothesize that these symptoms were due to misdiagnosed chronic exertional CS. Chronic CS is one of the differential diagnosis of chronic leg pain in athletes ${ }^{17}$. The syndrome most often affects the lower limbs, especially of runners and soccer players ${ }^{10-12,17}$. The athlete complains of an aching pain or a crampy ache in the lower legs during exercise. Temporary rest, or complete cessation of the activity may relive symptoms ${ }^{11,12}$.

Although the hypothesis of NMS was first considered in this case, the poor response to specific therapy makes this diagnosis less probable. Another differential diagnosis would be the serotonin syndrome. It is caused by excessive stimulation of $5 \mathrm{HT} 1 \mathrm{~A}$ receptors ad consists of shivering, salivation, confusion, agitation, and hyperthermia. Neuromuscular features include tremor, myoclonus, brisk reflexes and skeletal muscle rigidity leading to raised plasma CK. Rhabdomylolisis, although less common, is one of the clinical presentation ${ }^{18}$. It is usually caused by the interaction of selective serotonin reuptake inhibitor and another drug, but there are reports of with venlafaxine ${ }^{19}$.

Venlafaxine is dual (phenylethylamine) antidepressant that inhibits neuronal uptake of noraephinephrine, serotonine and dopamine (weakly). Adverse reactions are more related to autonomic nervous system (dry mouth), central nervous system (headache, somnolence), gastrointestinal system (nausea) $^{20}$. The are few cases of rhabdomyolysis ${ }^{21,22}$. It is unclear whether venlafaxine, or another drug was responsible for the rhabdomyolysis in this patient. He also received haloperidol which has been reported to cause rhabdomyolysis, usually associated to neuroleptic malignant syndrome and dystonic reaction ${ }^{23}$.

The incidence of drug interaction with venlafaxine has not been well studied. Drugs that inhibit cytochrome P450 isoenzyme 2D6 (CYP2D6), may precip- itate increases in venlafaxine plasma concentration. Some of the medication classes could cause these interactions are: beta-blockers (i.e. propranolol, metoprolol, timolol), other antidepressants (i.e. amytriptyline, nortriptyline) antiarrhythmics (i.e. propofenane, encainide), codeine and dexamethorphen ${ }^{19}$.

There are few reports of the interaction between haloperidol and venlafaxine ${ }^{24,25}$. Urinary retention was described ${ }^{24}$, but neuroleptic malignant syndrome, serotonin syndrome or rhabdomyolysis were not. An interplay between both drugs is probable since they are metabolized by the cytochrome P450 system. Haloperidol can act as an inhibitor, as well a stimulator, of CYP2D6. It is an inhibitor especially in high dosages ${ }^{25}$. Thus the administration of haloperidol in the post operative period could have contributed to a raise in the plasma levels of venlafaxine and its toxicity. Another important aspect is that patients with mood disorders in use of anti-depressants, especially selective serotonin-reuptake-inhibitors, are predisposed to have complications when submitted to surgical procedures, such as: hypotension, arrhythmias, changed thermoregulation, altered post-operative pain, differences in surgical stress response and postoperative confusion ${ }^{26}$.

The chronic CS associated to the drug interaction (haloperidol and venlafaxine) in the early postoperative period may also have contributed to the rhabdomyolisis and the acute compartment syndrome. Rhabdomyolisis refers to disintegration of striad muscle, which results in the release of muscular cells constituents into the extracellular fluid and circulation ${ }^{27}$. The enzyme CK is ubiquitously present in striad muscle. When muscle cells disintegrate, CK is released into the blood stream and it can be used as a diagnostic tool.

The rhabdomyolysis seen in this patient could be related to possible metabolic myopathy. Although the muscle biopsy did not show any finding of mithochondrial glycogen and lipid alteration, haloperidol and/or venlafaxine could explain this clinical condition $^{21,22,26}$.

In this report, our patient presented with different features which predisposed to this CS. He presented chronic exercise-induced CS which is a major risk for acute CS. He had mood disorder and was on chronic use of venlafaxine that increases the risk of complications after surgical procedures, as discussed above. He was submitted to a stressful situation, the rhytidoplasty, and due to discomfort in post-operative was medicated to haloperidol. Maybe, this was the last trigger to the rhabdomylolysis and conse- 
quent acute compartment syndrome. Although our patient had received gold-standard treatment, he left the hospital with a gait disturbance secondary to bilateral peroneal nerve injury.

\section{REFERENCES}

1. Matsen FA 3d,Winquist RA, Krugmire RB Jr. Diagnosis and management of compartmental syndromes. J Bone Joint Surg Am 1980;62:286-291.

2. Moore RE 3d, Friedman RJ. Current concepts in pathophysiology and diagnosis of compartment syndromes. J Emer Med 1989;7:657-662.

3. Hargens AR, Muburak SJ. Current concepts in the pathophysiology, evaluation, and diagnosis of compartment syndrome. Hand Clin 1998; 14:371-383.

4. Lydon JC, Spielman FJ. Bilateral compartment syndrome following prolonged surgery in the lithotomy position. Anesthesiology 1984;60:236-238.

5. Verdolin MH, Toth AS, Schroeder R. Bilateral lower extremity compartment syndromes prolonged surgery in the low lithotomy position with serial compression stockings. Anesthesiology 2000;92:1189-1191.

6. Moses TA, Kreder KJ, Thrasher JB. Compartment syndrome: an unusual complication of the lithotomy position. Urology 1994;43:746-747.

7. Tuckey J. Bilateral compartment syndrome complicating prolonged lithotomy position. Br J Anaesth 1996;77:546-549.

8. Kavouni A, Ion L. Bilateral well-leg compartment syndrome after supine position surgery. Ann Plast Surg 2000;44:462-463.

9. Holbein O, Strecker W, Rath SA, Kinzl L. Compartment syndrome of the thigh with sciatic nerve paralysis. Unfallchirurg 2000;103:275-280.

10. Englund J. Chronic compartment syndrome: tips on recognizing and treating. J Fam Pract 2005;54:955-960.

11. Klodell CT, Pokorny R, Carrillo EH, Heniford BT. Exercise-induced compartment syndrome: case report. Am Surg 1996;62:469-471.

12. Kahan JSG, McClellan RT, Burton DS. Acute bilateral compartment syndrome of the thigh induced by exercise. J Bone Joint Surg Am 1994; 76:862-864.
13. Lauder TD, Stuart MJ, Amrami KK, Felmlee JP. Exertional compartment syndrome and the role of magnetic resonance imaging. Am J Phys Med Rehabil 2002;81:315-319.

14. Ochoa-Gómez J, Villar-Arias A, Aresti I, Marco-Aguilar P. A case of severe hyperkalaemia and compartment syndrome due to rhabdomyolysis after drugs abuse. Resuscitation 2002;54:103-105.

15. Schneider JM, Roger DJ, Uhl RL. Bilateral forearm compartment syndrome resulting from neuroleptic malignant syndrome. J Hand Surg [Am] 1996;21:287-289.

16. Moyer JS, Baker SR. Complications of rhytidectomy. Facial Plast Surg Clin North Am 2005;13:469-478.

17. Edwards PH Jr, Wright ML, Hartman JF. A practical approach for the differential diagnosis of chronic leg pain in the athlete. Am J Sports Med 2005;33:1241-1249.

18. Prator BC. Serotonin syndrome. J Neurosci Nurs 2006;38:102-105.

19. Montanes-Rada F, Bilbao-Garay J, de Lucas-Taracena MT, Ortiz-Ortiz ME. Venlafaxine, serotonine syndrome, and differential diagnoses. J Clin Psychopharmacol 2005;25:101-102.

20. Ellingrod VL, Peny PJ. Venlafaxine: a heterocyclic antidepressent. Am J Hosp Pharm 1994;52:3033-3046.

21. Hanekamp BB, Zijlstra JG, Tulleken JE, Ligtenberg JJM, Van Der Werf TS, Hofstra LS. Serotonin syndrome and rhabdomyolysis in venlafaxine poisoning: a case report. Neth J Med 2005;63:316-318.

22. Oliver JJ, Kelly C, Jarvie D, Denieul S, Bateman DN. Venlafaxine poisoning complicated by a late rise in creatine kinase: two case reports. Hum Exp Toxicol 2002;21:463-466.

23. Levinson JL. Neuroleptic Malignant Syndrome. Am J Psychiatry 1985; 142:1137-1145.

24. Benazzi F. Urinary retention with venlafaxine-haloperdol combination. Pharmacopsychiatry 1997;30:27.

25. Kudo S, Ishizaki T. Pharmacokinetics of haloperidol: an update. Clin Pharmacokinet 1999;37:435-456.

26. De Baerdemaeker L, Audenaert K, Peremans K. Anaesthesia for patients with mood disorders. Curr Opin Anaesthesiol 2005;18:333-338.

27. Vanholder R, Sever MS, Erek E, Lameire N. Rhabdomyolysis. J Am Soc Nephrol 2000;11:1553-1561. 